OAK RIDGE NATIONAL LABORATORY

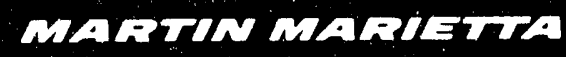

Characterization of Ventilation Ductwork in Building K-29 at the Oak Ridge K-25 Site

K. T. Klasson

S. L. Corder 
This report has been reproduced directly from the best available copy.

Available to DOE and DOE contractors from the Office of Scientific and Technical Information, P.O. Box 62, Oak Ridge, TN 37831; prices available from (615) 576-8401, FTS 626-8401.

Available to the public from the National Tectnical Information Service, U.S Department of Commerce, 5285 Port Royal Rd., Springtield, VA 22161.

This report was prepared as an account of work sponsored by an agency of the United States Government. Neither the United States Government nor any agency thereof, nor any of their employees, makes any warranty, express or implied, or assumes any legal liability or responsibility for the accuracy, completeness, or usefulness of any information, apparatus, product, or process disclosed, or represents that its use would not infringe privately owned rights. Reference herein to any specific commercial product, process, or service by trade name, trademark, manufacturer, or otherwise, does not necessarily constitute or imply its endorsement, recominendation, or favoring by the United States Government or any agency thereot. The views and opinions of authors expressed herein do not necessarily state or reflect those of the United States Government or any agency thereot. 


\section{CHARACTERIZATION OF VENTILATION DUCTWORK IN BUILDING K-29 AT THE OAK RIDGE K-25 SITE}

K. T. K!assen

S. L. Corder

Date Published: August 1993

Prepared by the

OAK RIDGE NATIONAL LABORATORY

Oak Ridge, Tennessee 37831-6285 managed by

MARTIN MARIETTA ENERGY SYSTEMS, INC.

for the

U.S. DEPARTMENT OF ENERGY under contract DE-AC05-84OR21400 


\section{CONTENTS}

LIST $\cap F$ TABLES $\ldots \ldots \ldots \ldots \ldots \ldots$

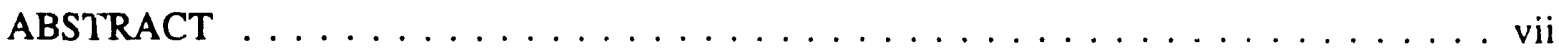

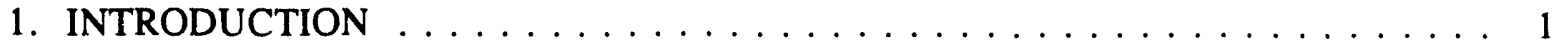

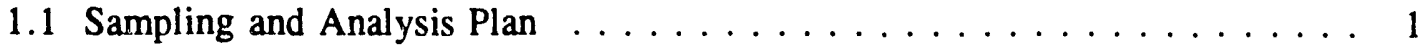

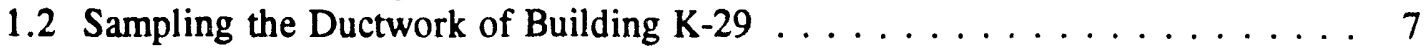

2. ANALYTICAL DATA FOR BUILDING K-29 DUCT SAMPLES . . . . . . . . 8

2.1 Wipe Samples from Main Plenums . . . . . . . . . . . . . 8

2.2 Wipe Samples from Side Laterals . . . . . . . . . . . . . . . . . . . 8

2.3 Metal Coupon Samples from Main Plenums and Side Laterals . . . . . . . . . 9

2.4 Bulk Sample . . . . . . . . . . . . . . . . . . . . . . . . . 9

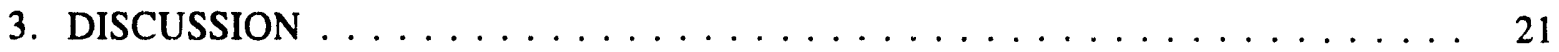

Appendix A-SAMPLE ID NUMBERS $\ldots \ldots \ldots \ldots \ldots$

Appendix B- RESULTS OF DUPLICATE WIPE ANALYSES IN BUILDING K-29 . . 29 


\section{LIST OF TABLES}

1. Sampling locations in main plenums of Building $\mathrm{K}-29 \ldots \ldots \ldots \ldots$

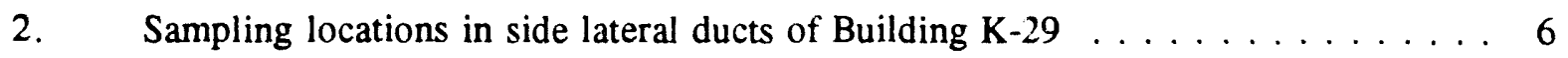

3. Kesults of analyses of wipe samples from main plenums in Building K-29 . . 10

4. Mean values of analyses for PCB, uranium, and technetium in main plenums of

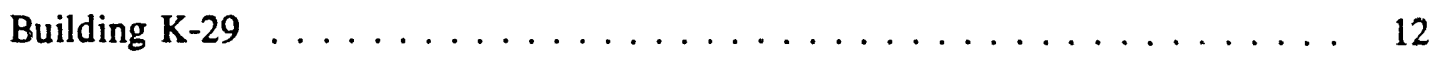

5. Ranges and highest analytical values for PCB, uranium, and tecinetium in main plenums of Building K-29 . . . . . . . . . . . . . . . . 12

6. Results of analyses of wipe samples from side laterals in Building $\mathrm{K}-29 \ldots \ldots$

7. Mean values of analyses for PCB, uranium, and technetium in side lateral ducts in Building $\mathrm{K}-29 \ldots \ldots \ldots \ldots \ldots \ldots \ldots \ldots$

8. Ranges and highest analytical values for $\mathrm{PCB}$, uranium, and technetium in main plenums of Building K-29 . . . . . . . . . . . . . . . . . 15

9. Analyses of metal coupons from main plenums in Building K-29 . . . . . . . 17

10. Analyses of metal coupons from side lateral ducts in Building K-29 _ . . . . 18

11. Analyses of composite bulk sample taken from side lateral duct at locations $\mathrm{W}-15, \mathrm{E}-3$, and B-5 in Building $\mathrm{K}-29 \ldots \ldots \ldots . \ldots 19$

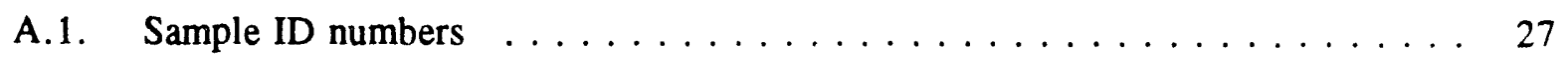

B.1. Results of duplicate wipe analyses in Building $\mathrm{K}-29 \ldots \ldots \ldots \ldots \ldots$ 


\begin{abstract}
An extensive sampling and analysis program was initiated in mid-October 1992 to characterize the ductwork of Building K-29 at the Oak Ridge K-25 Site. This building, 4 acres under roof, contains approximately 1500 feet of main exhaust ducts (plenums), not including the side laterals. A large number of hexane-moistened wipe samples were taken from randomly selected locations within the four main plenums and the side lateral ducts. Three wipes were taken from each location and were analyzed for polychlorinated biphenyls (PCBs), uranium, and technetium. These samples were augmented with 12 metal coupon samples (cut from the ducts) that were analyzed for radionuclides and subjected to Toxicity Characteristic Leaching Procedure analyses for toxic metals, base/neutral/acid compounds, and volatile organic compounds.
\end{abstract}

Based on the wipe analyses, with $95 \%$ confidence, $95 \%$ of the contamination levels in the ductwork are as follows. PCB levels are $<16,200$ and $<2300 \mu \mathrm{g} / 100 \mathrm{~cm}^{2}$ for the main plenums and side lateral ducts respectively; uranium levels are $<910$ and $<6770 \mu \mathrm{g} / 100 \mathrm{~cm}^{2}$ for the main plenums and side lateral ducts respectively; and technetium levels are $<16,100$ and $<65,000 \mathrm{pCi} / 100 \mathrm{~cm}^{2}$ for the main plenums and side laterals respectively. The levels of radiological contamination found would classify the main and side lateral ducts as contamination areas according to Energy Systems' standards for radiation protartion and its interpretation of Attachment 2 of DOE Order 5480.11. 


\section{INTRODUCTION}

Complete characterization of the interior of the ventilation ductwork in Building K-29 at the Oak Ridge K-25 Site would be a rather massive and costly undertaking. The building itself is large, with dimensions of 405 by $435 \mathrm{ft}$, or a total of 4 acres, under roof. The ventilation ductwork consists of four main plenums, each $367 \mathrm{ft}$ long (a total length of $1500 \mathrm{ft}$ ). The two main plenums in the center of the building are about $6 \mathrm{ft}$ wide, and the remaining two plenums on the east and west side of the building are about $4 \mathrm{ft}$ wide. A large number of side laterals intersect each main plenum. Each of the center plenums has approximately 42 lateral ducts, and each of the other plenums has 20 lateral ducts. Each side lateral duct is approximately 2 to $4 \mathrm{ft}$ in diameter, and the lateral ductwork on each side of the main plenums covers about a 60 - by $360-\mathrm{ft}$ area. A sampling plan to determine the general level and worst-case contamination for Building K-29 was designed by the Sampling and Environmental Support Department at the Oak Ridge K-25 Site.

\subsection{Sampling and Analysis Plan}

The sampling plan divided the ductwork for the building into two distinct sampling areas-the main plenums and the lateral ducts. Approximately half the samples for Building K-29 were taken from each area. Sixty areas were sampled in the main plenums, and another 60 areas were sampled in the side laterals. The number of samples (60) taken from each area was based on a statistical determination that, with a $95 \%$ confidence level, $95 \%$ of a large population of samples would yield analytical results which would not exceed the maximum analysis found within the sample population of 60 .

In the original sampling plan, each of the designated locations would be sampled by rubbing a hexane-moistened wipe on the inside surface of a duct. The wipe would then be divided in three parts, and the thirds analyzed for uranium, technetium, and polychlorinated biphenyls (PCBs) respectively. However, after completing the sampling in Building K-33, it was decided to collect three wipes at each location for Building K-29. Each wipe was rubbed over a different $100-\mathrm{cm}^{2}$ area, from the "arm-reachable area" (arm-reachable through a 12-by 12-in. hole cut into the side of the duct) on the bottom of the duct at the designated sampling point. Other samples to be taken were the actual metal coupons (originally 12 by 12 in. but cut to 10 
by $10 \mathrm{~cm}$ for the sample) that were cut from the lower side of the duct to allow hand entry for sampling. Bulk portions of material were to be collected if, in the sampler's judgment, they equaled or exceeded a total of $100 \mathrm{~g}$. The coupon openings were randomly alternated between the two sides of a duct whenever possible.

The sampler scanned the interior of the duct through the 12- by 12 -in. opening and recorded in a logbook appropriate comments concerning the surface conditions. All samples were subjected to careful identification and logging, packaging, chain of custody, and archiving requirements immediately after sampling as detailed in the sampling and analysis plan. The three wipes from each sampling location, representing $100 \mathrm{~cm}^{2}$ of interior duct surface area (per wipe), were submitted to the Quality and Technical Services Division (K-25 Site) for analysis of PCBs, uranium, and technetium. A random selection of $100-\mathrm{cm}^{2}$ pieces of metal coupons was subjected to analysis for radionuclides and to Toxicity Characteristic Leaching Procedure (TCLP; see 40 CFR Part 261, Appendix II) for toxic metals, base/neutral/acid compounds (BNAs), and volatile organic compounds (VOAs).

Sixty sampling locations were selected for the main plenums, and the same number of locations was selected for the side lateral ductwork. The locations were labeled as specific column numbers within K-29 and were randomly generated. During the course of the actual sampling process, 14 of the initially selected locations for the main plenums and 16 locations for the side laterals were found to be inaccessible for sampling. Alternative locations were selected on the same major plenum; for the side laterals, a nearby lateral attached to the same major plenum was chosen. Tables 1 and 2 in this report contain the column location data, with the alternative sampling location shown for each inaccessible location. The layout of the K-29 duct system may be seen in Fig. $1^{*}$. As in noted in the figure, all column numbers of the building are shown in respect to the main plenums and side laterals. A complete listing of the sample ID numbers (as recorded by the K-25 Analytical Chemistry Department) may be found in Appendix A.

\footnotetext{
Drawing M1E705020-A001 - reproduced in reduced form as Fig. 1.
} 


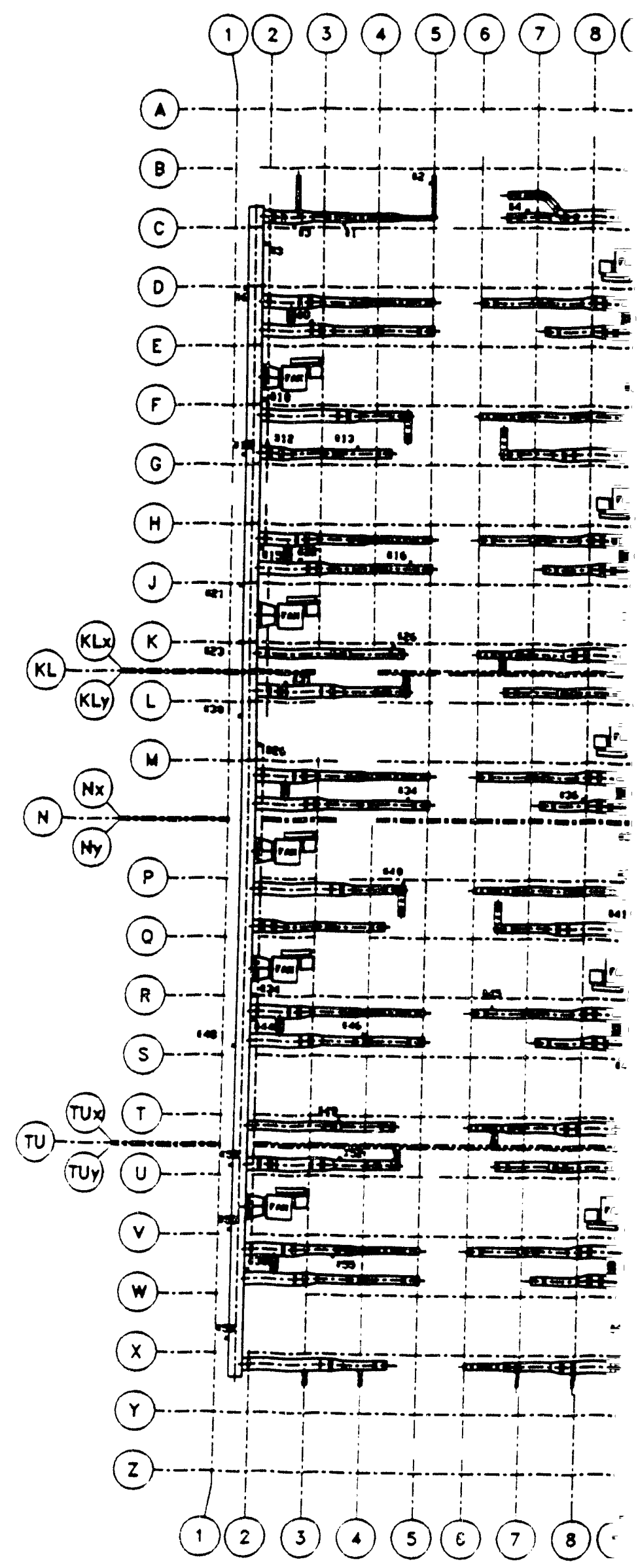

Fig. 1. Layout of main plenums and : 


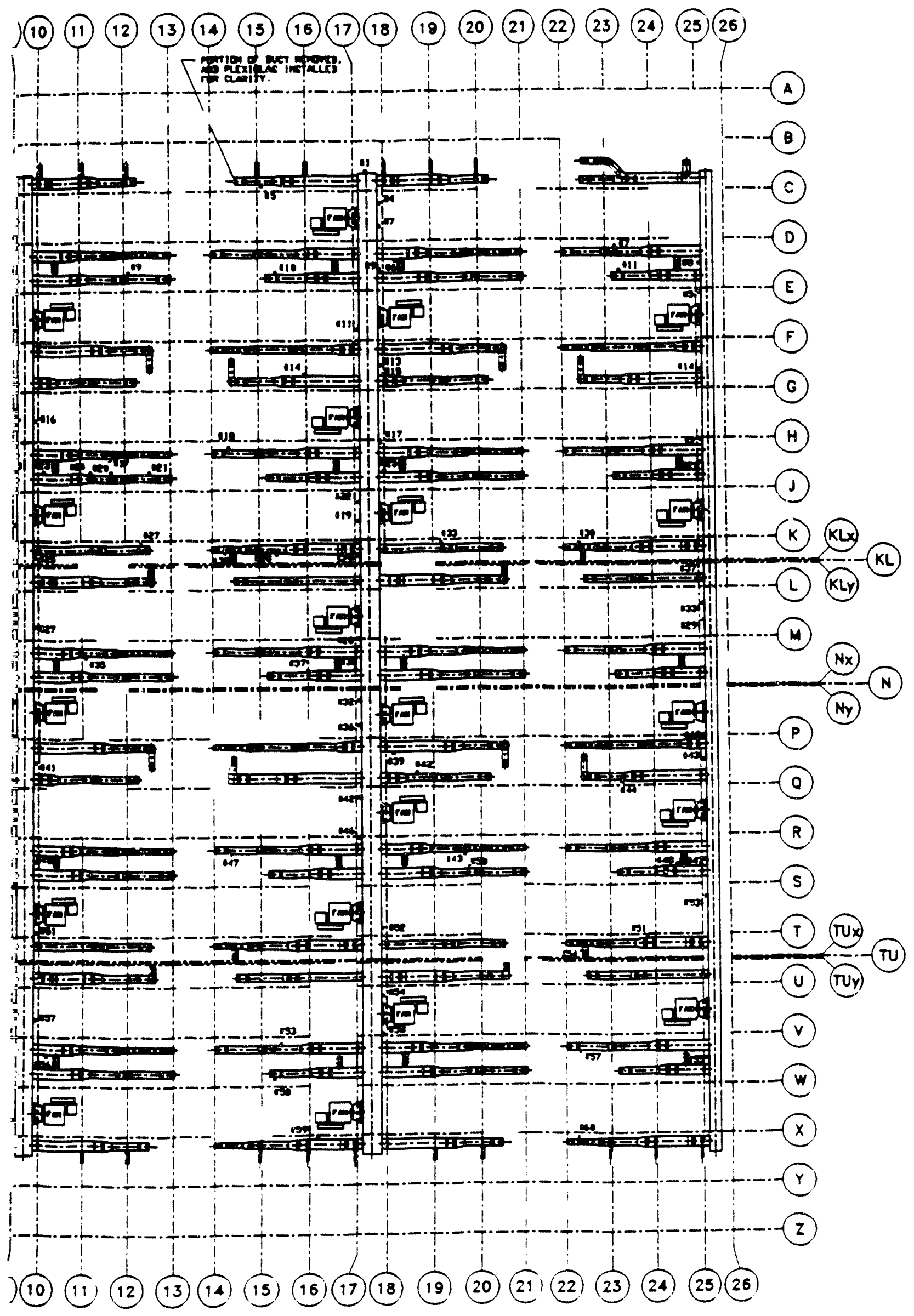

de laterals in Building K-29, showing column numbers and sampling locations. 
5

Table 1. Sampling locations in main plenums of Building K-29

\begin{tabular}{|c|c|c|c|c|c|}
\hline Sample no. & Column no. & $\begin{array}{l}\text { Alternate } \\
\text { location }^{\mathrm{a}}\end{array}$ & Sample no. & Column no. & $\begin{array}{l}\text { Alternate } \\
\text { location }^{\mathrm{a}}\end{array}$ \\
\hline 1 & B-17 & & 31 & $N-9$ & \\
\hline 2 & B-25 & $\mathrm{H}-25$ & 32 & $\mathrm{~N}-17$ & \\
\hline 3 & C-2 & & 33 & $\mathrm{~N}-25$ & L-25 \\
\hline 4 & $C-17$ & & 34 & $0-2$ & $\mathrm{R}-2$ \\
\hline 5 & $\mathrm{C}-25$ & E-25 & 35 & O-9 & F-9 \\
\hline 6 & D-2 & & 36 & $0-17$ & P-17 \\
\hline 7 & D-17 & & 37 & O-25 & L-25 \\
\hline 8 & D-25 & & 38 & P-2 & $\mathrm{V}-2$ \\
\hline 9 & E-17 & & 39 & P-9 & \\
\hline 10 & F-2 & & 40 & P-25 & \\
\hline 11 & F-17 & & 41 & Q-9 & \\
\hline 12 & G-2 & & 42 & Q-17 & \\
\hline 13 & G-17 & & 43 & Q-25 & \\
\hline 14 & G-25 & & 44 & $\mathrm{R}-2$ & \\
\hline 15 & $\mathrm{H}-2$ & & 45 & R-9 & \\
\hline 16 & H-9 & & 46 & $\mathrm{R}-17$ & \\
\hline 17 & $\mathrm{H}-17$ & & 47 & $\mathrm{R}-25$ & \\
\hline 18 & I-9 & $\mathrm{H}-9$ & 48 & $S-2$ & \\
\hline 19 & $\mathrm{I}-17$ & $\mathrm{~K}-17$ & 49 & S-9 & \\
\hline 20 & $\mathrm{I}-25$ & H-25 & 50 & $\mathrm{~T}-2$ & $\mathrm{~T}-17$ \\
\hline 21 & $\mathrm{~J}-2$ & & 51 & $\mathrm{~T}-9$ & \\
\hline 22 & $\mathrm{~J}-17$ & & 52 & $T-17$ & \\
\hline 23 & $\mathrm{~K}-2$ & & 53 & $\mathrm{~T}-25$ & \\
\hline 24 & K-9 & & 54 & $\mathrm{U}-17$ & \\
\hline 25 & L-9 & & 55 & U-25 & $V-25$ \\
\hline 26 & M-2 & & 56 & $V-2$ & \\
\hline 27 & M-9 & & 57 & $V-9$ & \\
\hline 28 & M-17 & & 58 & $V-17$ & \\
\hline 29 & M-25 & & 59 & $X-2$ & \\
\hline 30 & $\mathrm{~N}-2$ & L-2 & 60 & $X-9$ & \\
\hline
\end{tabular}

If the planned sampling location was inaccessible, the alternate location is listed. 
6

Table 2. Sampling locations in side lateral ducts of Building K-29

\begin{tabular}{|c|c|c|c|c|c|}
\hline Sample no. & Column no. & $\begin{array}{l}\text { Alternate } \\
\text { location }^{\mathrm{a}}\end{array}$ & Sample no. & Column no. & $\begin{array}{l}\text { Alternate } \\
\text { location }^{\mathrm{a}}\end{array}$ \\
\hline 1 & B-3 & $C-3$ & 31 & L-2 & \\
\hline 2 & B-5 & & 32 & L-14 & \\
\hline 3 & $\mathrm{C}-2$ & & 33 & L-19 & \\
\hline 4 & C-7 & & 34 & M-5 & \\
\hline 5 & $C-15$ & & 35 & M-11 & \\
\hline 6 & D-18 & & 36 & $\mathrm{~N}-8$ & \\
\hline 7 & D-23 & & 37 & $N-16$ & \\
\hline 8 & E-3 & & 38 & $\mathrm{~N}-17$ & \\
\hline 9 & E-13 & & 39 & O-18 & P-18 \\
\hline 10 & E-15 & & 40 & $Q-4$ & P-5 \\
\hline 11 & E-23 & & 41 & Q-9 & \\
\hline 12 & G-2 & & 42 & Q-19 & \\
\hline 13 & $\mathrm{G}-4$ & & 43 & Q-22 & R-20 \\
\hline 14 & G-16 & & 44 & Q-23 & \\
\hline 15 & G-18 & & 45 & $R-6$ & \\
\hline 16 & $\mathrm{H}-5$ & & 46 & S-6 & $S-4$ \\
\hline 17 & $\mathrm{H}-12$ & & 47 & $S-14$ & $\mathrm{R}-14$ \\
\hline 18 & $\mathrm{H}-14$ & & 48 & $S-25$ & \\
\hline 19 & I-9 & H-9 & 49 & $T-6$ & $T-4$ \\
\hline 20 & $\mathrm{I}-12$ & $\mathrm{~J}-12$ & 50 & $T-21$ & $S-20$ \\
\hline 21 & $\mathrm{I}-13$ & $J-13$ & 51 & $T-24$ & \\
\hline 22 & $\mathrm{~J}-2$ & & 52 & $U-6$ & $U-4$ \\
\hline 23 & $J-10$ & & 53 & (I) -14 & $V-14$ \\
\hline 24 & $\mathrm{~J}-11$ & & 54 & U-22 & \\
\hline 25 & $\mathrm{~J}-18$ & & 55 & $V-4$ & \\
\hline 26 & $\mathrm{~K}-4$ & & 56 & $V-10$ & \\
\hline 27 & $\mathrm{~K}-12$ & & 57 & $V-22$ & \\
\hline 28 & $K-15$ & & 58 & W-15 & $W-15$ \\
\hline 29 & K-18 & & 59 & $W-16$ & $X-16$ \\
\hline 30 & K-22 & & 60 & $X-21$ & $X-22$ \\
\hline
\end{tabular}

af the planned sampling location was inaccessible, the alternate location is listed. 


\subsection{Sampling the Ductwork of Building K-29}

Sampling of the ductwork of Building K-29 began on October 12, 1992, and was competed on December 16, 1992. During this period, 131 wipe samples were taken, of which 11 vere duplicates. Each wipe sample consisted of three wipes. The wipe samples were analyzed for PCBs, uranium, and technetium (one analysis per wipe) according to the methods listed in the sampling and analysis plan. Twelve metal coupon samples and one composite bulk sample were taken and submitted for radionuclide and TCLP analyses (see Sect. 1.1).

The procedure required to sample the ductwork involved five people and at least three departments, including Sampling and Environmental Support, Health Physics (HP), and Maintenance. A Veri-lift was utilized to position the individuals adjacent to the duct for the actual sampling. HP technicians surveyed the exterior where the opening was to be made prior to actually cutting into the duct. The external survey of the duct was discontinued after a survey of the first couple of sampling areas revealed no external contamination. A 12- by 12-in. template was used to mark the duct, and a transparent glove bag containing cutting tools and equipment to perform the actual sampling was duct-taped to the metal around the area to be clit. Holes were drilled around the periphery of the marked area, and nippers were employed to complete the opening.

The glove bag and the size of the opening tended to restrict the view of the interior of the duct by the sampling technicians. Their reports concerning the appearance of the duct generally indicated a layer of dust. In some instances, a heavy, oily-appearing dust with brown "gravel" or debris was noted. A bulk sample of this substance was collected as a composite sample from three locations. After completion of the sampling event, tools and samples were bagged from the duct by twisting the glove bag around them. Following the HP survey, which indicated that the samples were safe to remove, the samples were bagged and tagged. The HP technician again surveyed the area around the opening. after which it was taped shut. 


\section{ANALYTICAL DATA FOR BUILDING K-29 DUCT SAMPLES}

A number of hexane-moistened wipe samples (132), including 11 duplicates taken from the ductwork of Building K-29, were analyzed. Each wipe sample consisted of three wipes for the three assays (PCBs, uranium, and technetium); the reported analyses were thus based on a wipe area of $100 \mathrm{~cm}^{2}$. One hundred nineteen metal coupons $\left(100 \mathrm{~cm}^{2}\right)$ were taken, of which 12 were analyzed for radionuclides and for toxic metals, base/neutral/acid compounds (BNAs), and volatile organic compounds (VOAs) by TCLP. One composite bulk sample was also taken and analyzed for radionuclides and by TCLP for toxic metals, BNAs, and VOAs.

An appreciation for the variability in the samples can be gained by reviewing the results for duplicate wipe samples in Appendix B.

\subsection{Wipe Samples from Main Plenums}

The analytical data (PCBs, uranium, and technetium) obtained for the wipe samples from the main plenums of K-29 are listed in Table 3. The data are separated and listed for each of the seven main plenums in K-29 with the mean value $(\overline{\mathbf{x}})$ and sample standard deviation (s) listed in bold. In Table 4 , these data are summarized as mean values of analysis \pm tolerance intervals for each main plenum, together with the number of samples iaken from the particular plenum. Tolerance intervals were calculated based on the equation $\bar{x} \pm k s$, where $\bar{x}$ is the mean, $s$ is the sample standard deviation, and $k$ may be found in statistical tables. The tolerance limit was chosen to encompass $95 \%$ of all measurements with $95 \%$ confidence.

The ranges (tolerance intervals) for all main plenums in K-29 are listed in Table 5, together with the highest measured concentrations of PCBs, uranium, and technetium in each main plenum. Note that the highest actual measured concentration may be less than or greater than the statistically-derived tolerance limit.

\subsection{Wipe Samples from Side Laterals}

The assays of PCBs, uranium, and technetium for hexane-moistened wipes from the side lateral ductwork of Building K-29 are listed in Table 6. The results are grouped by major duct to which the side lateral is attached, and the mean values $(\overline{\mathbf{x}})$ and sample standard deviations (s) 
are listed in bold. The mean values of the analyses, number of samples, the ranges (tolerance intervals), and the highest values for each of the three constituents have been grouped as described above and summarized in Tables 7 and 8 respectively.

\subsection{Metal Coupon Samples from Main Plenums and Side Laterals}

One hundred nineteen metal coupon samples (area of $100 \mathrm{~cm}^{2}$ each) were obtained from the ductwork of Building K-29. Twelve coupon samples were submitted for analysis; the remaining amsples were archived. As mentioned before, the coupon samples were analyzed for radionuclides and by TCLP for toxic metals, BNAs, and VOAs. Six samples were taken from main plenums, and the remaining six were taken from the side laterals. The results of the radiological analyses are listed in Tables 9 and 10 for the main plenums and side lateral ducts respectively.

\subsection{Bulk Sample}

One composite bulk sample was collected by gathering loose deposits inside the side lateral ducts at locations W-15, E-3, and B-5. The materials were combined into one composite sample and analyzed for radionuclides anc' by TCLP for toxic metals, BNAs, and VOAs. The results of the analyses are listed in Table 11. 
Table 3. Results of analyses of wipe samples from main plenums in Building K-29

\begin{tabular}{|c|c|c|c|}
\hline \multirow[b]{2}{*}{ Column no. } & \multicolumn{3}{|c|}{ Analysis } \\
\hline & $\begin{array}{c}\text { PCB } \\
\left(\mu \mathrm{g} / 100 \mathrm{~cm}^{2}\right)\end{array}$ & $\begin{array}{c}\text { Uranium } \\
\left(\mu \mathrm{g} / 100 \mathrm{~cm}^{2}\right)\end{array}$ & $\begin{array}{c}\text { Technetium } \\
\left(\mathrm{pCi} / 100 \mathrm{~cm}^{2}\right)\end{array}$ \\
\hline C-2 & 85 & 290 & $1,980 \pm 600$ \\
\hline D-2 & 18 & 890 & $1,960 \pm 550$ \\
\hline F-2 & 14 & 470 & $875 \pm 700$ \\
\hline G-2 & 16 & 880 & $1,500 \pm 630$ \\
\hline $\mathrm{H}-2$ & 11 & 440 & $1.900 \pm 650$ \\
\hline $\mathrm{J}-2$ & 32 & 840 & $6,100 \pm 770$ \\
\hline $\mathrm{K}-2$ & 23 & 740 & $3,450 \pm 690$ \\
\hline M-2 & 7 & 690 & $5,390 \pm 700$ \\
\hline L-2 & 2.8 & 280 & $1,870 \pm 2,800$ \\
\hline R-2 & 8.2 & 600 & $4,130 \pm 2,800$ \\
\hline V-2 & 51 & 440 & $6,530 \pm 870$ \\
\hline R-2 & 36 & 450 & $10,000 \pm 820$ \\
\hline S-2 & 26 & 170 & $1,050 \pm 570$ \\
\hline$T-17$ & 73 & 440 & $2,930 \pm 630$ \\
\hline$V-2$ & 79 & 290 & $2,690 \pm 620$ \\
\hline \multirow[t]{3}{*}{$X-2$} & 51,000 & 1,200 & $6,360 \pm 730$ \\
\hline & $\overline{\mathbf{x}}=3,217.6$ & $\bar{x}=569$ & $\bar{x}=3,670$ \\
\hline & $s=12,742.0$ & $s=281$ & $s=2,552$ \\
\hline H-9 & 6.6 & 820 & $549 \pm 560$ \\
\hline H-9 & 22 & 220 & $1,350 \pm 490$ \\
\hline K-9 & 5 & 570 & $2,860 \pm 500$ \\
\hline L-9 & 15 & 220 & $2,780 \pm 490$ \\
\hline M-9 & 3.3 & 280 & $5,090 \pm 560$ \\
\hline N-9 & 2.2 & 160 & $2,710 \pm 530$ \\
\hline F-9 & 10 & 590 & $6,350 \pm 2,200$ \\
\hline P-9 & 4.3 & 170 & $3,470 \pm 560$ \\
\hline Q-9 & 2.3 & 130 & $2,120 \therefore 520$ \\
\hline R-9 & 17 & 170 & $5,430 \pm 610$ \\
\hline S-9 & 35 & 160 & $8,230 \pm 680$ \\
\hline$T-9$ & 9.3 & 210 & $4,490 \pm 580$ \\
\hline V-9 & 33 & 150 & $4,450 \pm 580$ \\
\hline \multirow[t]{3}{*}{$X-9$} & 9.4 & 105 & $3,700 \pm 560$ \\
\hline & $\bar{x}=12.5$ & $\bar{x}=283$ & $\bar{x}=3,827$ \\
\hline & $s=10.8$ & $s=216$ & $s=2,037$ \\
\hline
\end{tabular}


Table 3 (continued)

\begin{tabular}{|c|c|c|c|}
\hline \multirow[b]{2}{*}{ Column no. } & \multicolumn{3}{|c|}{ Analysis } \\
\hline & $\begin{array}{c}\text { PCB } \\
\left(\mu \mathrm{g} / 100 \mathrm{~cm}^{2}\right)\end{array}$ & $\begin{array}{c}\text { Uranium } \\
\left(\mu \mathrm{g} / 100 \mathrm{~cm}^{2}\right)\end{array}$ & $\begin{array}{l}\text { Technetium } \\
\left(\mathrm{pCi} / 100 \mathrm{~cm}^{2}\right)\end{array}$ \\
\hline B-17 & 1.6 & 190 & $2,900 \pm 2,100$ \\
\hline$C-17$ & 50 & 480 & $17,000 \pm 2,600$ \\
\hline D-17 & 3.4 & 150 & $5,710 \pm 2,200$ \\
\hline E-17 & 3.7 & 140 & $4,780 \pm 2,200$ \\
\hline F-17 & 77 & 120 & $3,150 \pm 780$ \\
\hline G-17 & 1.1 & 170 & $6,270 \pm, 1600$ \\
\hline $\mathrm{H}-17$ & 1.6 & 110 & $2,480 \pm 760$ \\
\hline $\mathrm{K}-17$ & 4 & 390 & $4.330 \pm 810$ \\
\hline$J-17$ & 61 & 200 & $4,640 \pm 820$ \\
\hline$M-17$ & 2.7 & 160 & $3,310 \pm 1,100$ \\
\hline $\mathrm{N}-17$ & 40 & 310 & $13,400 \pm 1,400$ \\
\hline P-17 & 40 & 130 & $12,800 \pm 1,400$ \\
\hline Q-17 & 3.9 & 38 & $6,600 \pm 1,200$ \\
\hline R-17 & 5 & 99 & $8,690 \pm 1,300$ \\
\hline$T-17$ & 3.4 & 61 & $4,97 v \div 1,200$ \\
\hline U-17 & 18 & 130 & $12,900 \pm 1,400$ \\
\hline \multirow[t]{3}{*}{$V-17$} & 4.5 & 140 & $5,470 \pm 700$ \\
\hline & $\bar{x}=18.9$ & $\overline{\mathbf{x}}=178$ & $\bar{x}=7,029$ \\
\hline & $s=24.7$ & $s=115$ & $s=4,356$ \\
\hline H-25 & 2.1 & 91 & $240 \pm 2,700$ \\
\hline E-25 & 21 & 210 & $4,310 \pm 1,500$ \\
\hline D-25 & 16 & 470 & $3,000 \pm 1,400$ \\
\hline G-25 & 9.7 & 560 & $7,300 \pm 1,600$ \\
\hline H-25 & 3.9 & 400 & $5,860 \pm 1,500$ \\
\hline$M-25$ & 91 & 140 & $5,550 \pm 1,500$ \\
\hline L-25 & 2.2 & 59 & $1,270 \pm 2,700$ \\
\hline L-25 & 3.2 & 100 & $2,670 \pm 2,800$ \\
\hline P-25 & 1.9 & 99 & $21,800 \pm 2,000$ \\
\hline Q-25 & 3.9 & 76 & $16,000 \pm 1,800$ \\
\hline R-25 & 3.6 & 120 & $17,400 \pm 1,800$ \\
\hline $\mathrm{T}-25$ & 2.2 & 96 & $7,230 \pm 2,900$ \\
\hline \multirow[t]{3}{*}{$V-25$} & 3.1 & 220 & $9,760 \pm 3,000$ \\
\hline & $\bar{x}=12.6$ & $\bar{x}=203$ & $\bar{x}=7,876$ \\
\hline & $s=24.3$ & $s=166$ & $s=6,645$ \\
\hline
\end{tabular}


Table 4. Mean values of analyses for PCB, uranium, and technetium in main plenums of Building K-29

\begin{tabular}{ccccccc}
\hline \multirow{2}{*}{$\begin{array}{c}\text { Main } \\
\text { plenum no. }\end{array}$} & $\begin{array}{c}\text { PCB } \\
\left(\mu \mathrm{g} / 100 \mathrm{~cm}^{2}\right)\end{array}$ & \multicolumn{5}{c}{$\begin{array}{c}\text { Mranium } \\
\left(\mu \mathrm{g} / 100 \mathrm{~cm}^{2}\right)\end{array}$} \\
\cline { 2 - 7 } & & & & & $\begin{array}{c}\text { Technetium } \\
\left(\mathrm{pCi} / 100 \mathrm{~cm}^{2}\right)\end{array}$ \\
\hline & $3,217.6 \pm 36,990.0$ & $(16)^{\mathrm{b}}$ & $569 \pm 817$ & $(16)$ & $3,670 \pm 7,407$ & $(16)$ \\
9 & $12.5 \pm 32.6$ & $(14)$ & $283 \pm 651$ & $(14)$ & $3,827 \pm 6,137$ & $(14)$ \\
17 & $18.9 \pm 70.5$ & $(17)$ & $178 \pm 328$ & $(17)$ & $7,029 \pm 12,450$ & $(17)$ \\
25 & $12.6 \pm 74.9$ & $(13)$ & $203 \pm 512$ & $(13)$ & $7,876 \pm 20,474$ & $(13)$ \\
\end{tabular}

'Range indicated is according to a tolerance interval so that one can assert, with $95 \%$ confidence, that the given limits will contain at least $95 \%$ of all measurements.

'Number within parentheses indicates how many samples were taken and analyzed.

Table 5. Ranges and highest analytical values for PCB, uranium, and technetium in main plenums of Building K-29

\begin{tabular}{ccccccc}
\hline \multirow{2}{*}{$\begin{array}{c}\text { Main } \\
\text { plenum no. }\end{array}$} & $\begin{array}{c}\text { RCB } \\
\left(\mu \mathrm{g} / 100 \mathrm{~cm}^{2}\right)\end{array}$ & $\begin{array}{c}\text { Highest } \\
\text { value }\end{array}$ & $\begin{array}{c}\text { Uranium } \\
\left(\mu \mathrm{g} / 100 \mathrm{~cm}^{2}\right)\end{array}$ & $\begin{array}{c}\text { Highest } \\
\text { value }\end{array}$ & $\begin{array}{c}\text { Technetium } \\
\left(\mathrm{pCi} / 100 \mathrm{~cm}^{2}\right)\end{array}$ & $\begin{array}{c}\text { Highest } \\
\text { value }\end{array}$ \\
\cline { 3 - 7 } & & & & & & \\
2 & $0-40,208$ & 51,000 & $0-1,387$ & 1,200 & $0-11,077$ & 10,000 \\
9 & $0-45.1$ & 35 & $0-933$ & 820 & $0-9,964$ & 8,230 \\
17 & $0-89.4$ & 77 & $0-505$ & 480 & $0-19,479$ & 17,000 \\
25 & $0-87.5$ & 91 & $0-715$ & 560 & $0-28,350$ & 21,800
\end{tabular}

'Range of values is mean value \pm the tolerance interval. When the low-range value is negative, it is set to zero.

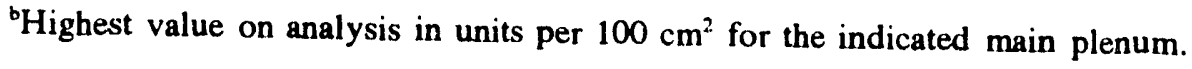


Table 6. Results of analyses of wipe samples from side laterals in Building K-29 (grouped by main duct)

\begin{tabular}{|c|c|c|c|}
\hline \multirow[b]{2}{*}{ Column no. } & \multicolumn{3}{|c|}{ Analysis } \\
\hline & $\begin{array}{c}\text { РCB } \\
\left(\mu \mathrm{g} / 100 \mathrm{~cm}^{2}\right)\end{array}$ & $\begin{array}{c}\text { Uranium } \\
\left(\mu \mathrm{g} / 100 \mathrm{~cm}^{2}\right)\end{array}$ & $\begin{array}{c}\text { Technetium } \\
\left(\mathrm{pCi} / 100 \mathrm{~cm}^{2}\right)\end{array}$ \\
\hline$C-3$ & 24 & 700 & $1,590 \pm 500$ \\
\hline B-5 & 110 & 830 & $3,200 \pm 040$ \\
\hline$C-2$ & 9 & 1,000 & $8,560 \pm 780$ \\
\hline $\mathrm{E}-3$ & 310 & 2,400 & $11,100 \pm 890$ \\
\hline G-2 & 29 & 1,900 & $1,020 \pm 710$ \\
\hline$G-4$ & 5.4 & 52 & $1,170 \pm 620$ \\
\hline $\mathrm{H}-5$ & 14 & 1,300 & $4,330 \pm 720$ \\
\hline$J-2$ & 71 & 1,600 & $3,920 \pm 800$ \\
\hline$K-4$ & 280 & 1,500 & $6,180 \pm 860$ \\
\hline$L-2$ & 11 & 170 & $6,130 \pm 720$ \\
\hline M-5 & 31 & 360 & $15,300 \pm 820$ \\
\hline P-5 & 53 & 520 & $21,900 \pm 940$ \\
\hline$R-6$ & 100 & 400 & $35,100 \pm 1100$ \\
\hline$S-4$ & 66 & 180 & $9.770 \pm 710$ \\
\hline$T-4$ & 74 & 260 & $5,760 \pm 620$ \\
\hline$U-4$ & 52 & 480 & $11,600 \pm 750$ \\
\hline \multirow[t]{3}{*}{$V-4$} & 3 & 200 & $2,700 \pm 530$ \\
\hline & $\bar{x}=73.1$ & $\bar{x}=815$ & $\bar{x}=8,784$ \\
\hline & $s=89.8$ & $s=695$ & $s=8,754$ \\
\hline $\mathrm{C}-7$ & 17 & 1,600 & $11.200 \pm 890$ \\
\hline E-13 & 180 & 19,000 & $26,400 \pm 2,800$ \\
\hline H-12 & 64 & 3,800 & $12,200 \pm 860$ \\
\hline $\mathrm{H}-9$ & 6.6 & 170 & $3,180 \pm 640$ \\
\hline $\mathrm{J}-12$ & 16 & 1,000 & $5,560 \pm 570$ \\
\hline $\mathrm{J}-13$ & 120 & 1,100 & $10,900 \pm 2400$ \\
\hline$J-10$ & 1.4 & 610 & $9,630 \pm 810$ \\
\hline $\mathrm{J}-11$ & 164 & 1,700 & $36,200 \pm 1,300$ \\
\hline $\mathrm{K}-12$ & 98 & 670 & $7,090 \pm 740$ \\
\hline L-14 & 61 & 570 & $9,350 \pm 950$ \\
\hline M-11 & 92 & 230 & $908 \pm 440$ \\
\hline $\mathrm{N}-8$ & 4.5 & 290 & $5,580 \pm 610$ \\
\hline Q-9 & 2.3 & 270 & $9,200 \pm 700$ \\
\hline \multirow[t]{3}{*}{$V-10$} & 2.7 & 30 & $1.020 \pm 480$ \\
\hline & $\bar{x}=59.3$ & $\bar{x}=2,217$ & $\bar{x}=10,601$ \\
\hline & $s=62.7$ & $s=4,928$ & $s=9,672$ \\
\hline
\end{tabular}


Table 6 (continued)

\begin{tabular}{|c|c|c|c|}
\hline \multirow[b]{2}{*}{ Column no. } & \multicolumn{3}{|c|}{ Analysis } \\
\hline & $\begin{array}{c}\text { PCB } \\
\left(\mu \mathrm{g} / 100 \mathrm{~cm}^{2}\right)\end{array}$ & $\begin{array}{c}\text { Uranium } \\
\left(\mu \mathrm{g} / 100 \mathrm{~cm}^{2}\right)\end{array}$ & $\begin{array}{c}\text { Technetium } \\
\left(\mathrm{pCi} / 100 \mathrm{~cm}^{2}\right)\end{array}$ \\
\hline$C-15$ & 45 & 240 & $15,500 \pm 3,200$ \\
\hline D-18 & 1,400 & 370 & $15,600 \pm 1,100$ \\
\hline E-15 & 260 & 760 & $51,800 \pm 4,100$ \\
\hline G-16 & 50 & 2,100 & $14,600 \pm 1,800$ \\
\hline G-18 & 11 & 1,500 & $7,980 \pm 1,600$ \\
\hline H-14 & 8.8 & 520 & $14,300 \pm 3,100$ \\
\hline$J-18$ & 1.2 & 150 & $3,580 \pm 790$ \\
\hline $\mathrm{K}-15$ & 64 & 1,400 & $47,100 \pm 2,500$ \\
\hline$K-18$ & 33 & 280 & $14,900 \pm 1,800$ \\
\hline L-19 & 8.3 & 1,100 & $18,100 \pm 1,900$ \\
\hline$N-16$ & 68 & 270 & $7.540 \pm 1,200$ \\
\hline $\mathrm{N}-17$ & 57 & 450 & $6,120 \pm 1,200$ \\
\hline P-18 & 5.1 & 420 & $11,100 \pm 1,300$ \\
\hline Q-19 & 4 & 270 & $8,640 \pm 1,300$ \\
\hline R-20 & 14 & 980 & $16,300 \pm 1,800$ \\
\hline R-14 & 8.3 & 140 & $19,000 \pm 1,200$ \\
\hline$S-20$ & 30 & 1,500 & $36,400 \pm 1,500$ \\
\hline$V-14$ & 1,100 & 26 & $6,240 \pm 860$ \\
\hline$W-15$ & 6,800 & 240 & $10,600 \pm 830$ \\
\hline \multirow[t]{3}{*}{$X-16$} & 28 & 750 & $32,000 \pm 1,200$ \\
\hline & $\bar{x}=499.8$ & $\bar{x}=673$ & $\bar{x}=17,870$ \\
\hline & $s=1,530.4$ & $s=575$ & $s=13,497$ \\
\hline D-23 & 46 & 890 & $11,600 \pm 2,400$ \\
\hline E-23 & 200 & 250 & $10,400 \pm 2,400$ \\
\hline $\mathrm{K}-22$ & 19 & 480 & $9,190 \pm 1,600$ \\
\hline Q-23 & 40 & 89 & $18,300 \pm 1,900$ \\
\hline S-25 & 7.8 & 230 & $25,500 \pm 1,300$ \\
\hline$T-24$ & 62 & 87 & $36,700 \pm 1,500$ \\
\hline $\mathrm{U}-22$ & 0.66 & 34 & $3,830 \pm 790$ \\
\hline$V-22$ & 70 & 820 & $152,000 \pm 2,800$ \\
\hline \multirow[t]{3}{*}{$X-22$} & 5.9 & 380 & $9,890 \pm 960$ \\
\hline & $\bar{x}=50.2$ & $\bar{x}=362$ & $\bar{x}=30,823$ \\
\hline & $s=61.5$ & $s=314$ & $s=46,536$ \\
\hline
\end{tabular}


Table 7. Mean values of analyses for PCB, uranium, and technetium in side lateral ducts in Building K-29

\begin{tabular}{ccccccc}
\hline & \multicolumn{5}{c}{ Mean analyses and range } \\
\cline { 2 - 7 } $\begin{array}{c}\text { Main } \\
\text { plenum no. }\end{array}$ & $\begin{array}{c}\text { PCB } \\
\left(\mu \mathrm{g} / 100 \mathrm{~cm}^{2}\right)\end{array}$ & \multicolumn{5}{c}{$\begin{array}{c}\text { Uranium } \\
\left(\mu \mathrm{g} / 100 \mathrm{~cm}^{2}\right)\end{array}$} \\
\hline & & & & $\begin{array}{c}\text { Technetium } \\
\left(\mathrm{pCi} / 100 \mathrm{~cm}^{2}\right)\end{array}$ \\
2 & $73.1 \pm 256.6$ & $(17)$ & $815 \pm 1,986$ & $(17)$ & $8,784 \pm 25,018$ & $(17)$ \\
9 & $59.3 \pm 188.8$ & $(14)$ & $2,217 \pm 14,842$ & $(14)$ & $10,601 \pm 29,133$ & $(14)$ \\
17 & $499.8 \pm 4,211.7$ & $(20)$ & $673 \pm 1,582$ & $(20)$ & $17,870 \pm 37,145$ & $(20)$ \\
25 & $50.2 \pm 217.3$ & $(9)$ & $362 \pm 1,110$ & $(9)$ & $30,823 \pm 164,366$ & $(9)$ \\
& & & & & &
\end{tabular}

-Range indicated is according to a tolerance interval so that one can assert, with $95 \%$ confidence, that the given limits will contain at least $95 \%$ of all measurements.

${ }^{b}$ Number within parentheses indicates how many samples were taken and analyzed.

Table 8. Ranges and highest analytical values for PCB, uranium, and technetium in main plenums of Building K-29

\begin{tabular}{|c|c|c|c|c|c|c|}
\hline \multirow[b]{2}{*}{$\begin{array}{c}\text { Main } \\
\text { plenum no. }\end{array}$} & \multicolumn{6}{|c|}{ Range and highest ${ }^{\mathrm{b}}$ value } \\
\hline & $\begin{array}{c}\text { PCB } \\
\left(\mu \mathrm{g} / 100 \mathrm{~cm}^{2}\right)\end{array}$ & $\begin{array}{l}\text { Highest } \\
\text { value }\end{array}$ & $\begin{array}{c}\text { Uranium } \\
\left(\mu \mathrm{g} / 100 \mathrm{~cm}^{2}\right)\end{array}$ & $\begin{array}{l}\text { Highest } \\
\text { value }\end{array}$ & $\begin{array}{l}\text { Technetium } \\
\left(\mathrm{pCi} / 100 \mathrm{~cm}^{2}\right)\end{array}$ & $\begin{array}{l}\text { Highest } \\
\text { value }\end{array}$ \\
\hline 2 & $0-329.7$ & 310 & $0-2,801$ & 2,400 & $0-33,802$ & 35,100 \\
\hline 9 & $0-248.0$ & 180 & $0-17,059$ & 19,000 & $0-39,734$ & 36,200 \\
\hline 17 & $0-4,711.5$ & 6,800 & $0-2,256$ & 2,100 & $0-55,015$ & 51,800 \\
\hline 25 & $0-267.5$ & 200 & $0-1,472$ & 890 & $0-195,189$ & 152,000 \\
\hline
\end{tabular}

'Range of values is mean value \pm the tolerance interval. When the low-range value is negative, it is set to zero.

bHighest value on analysis in units per $100 \mathrm{~cm}^{2}$ for the indicated main plenum. 


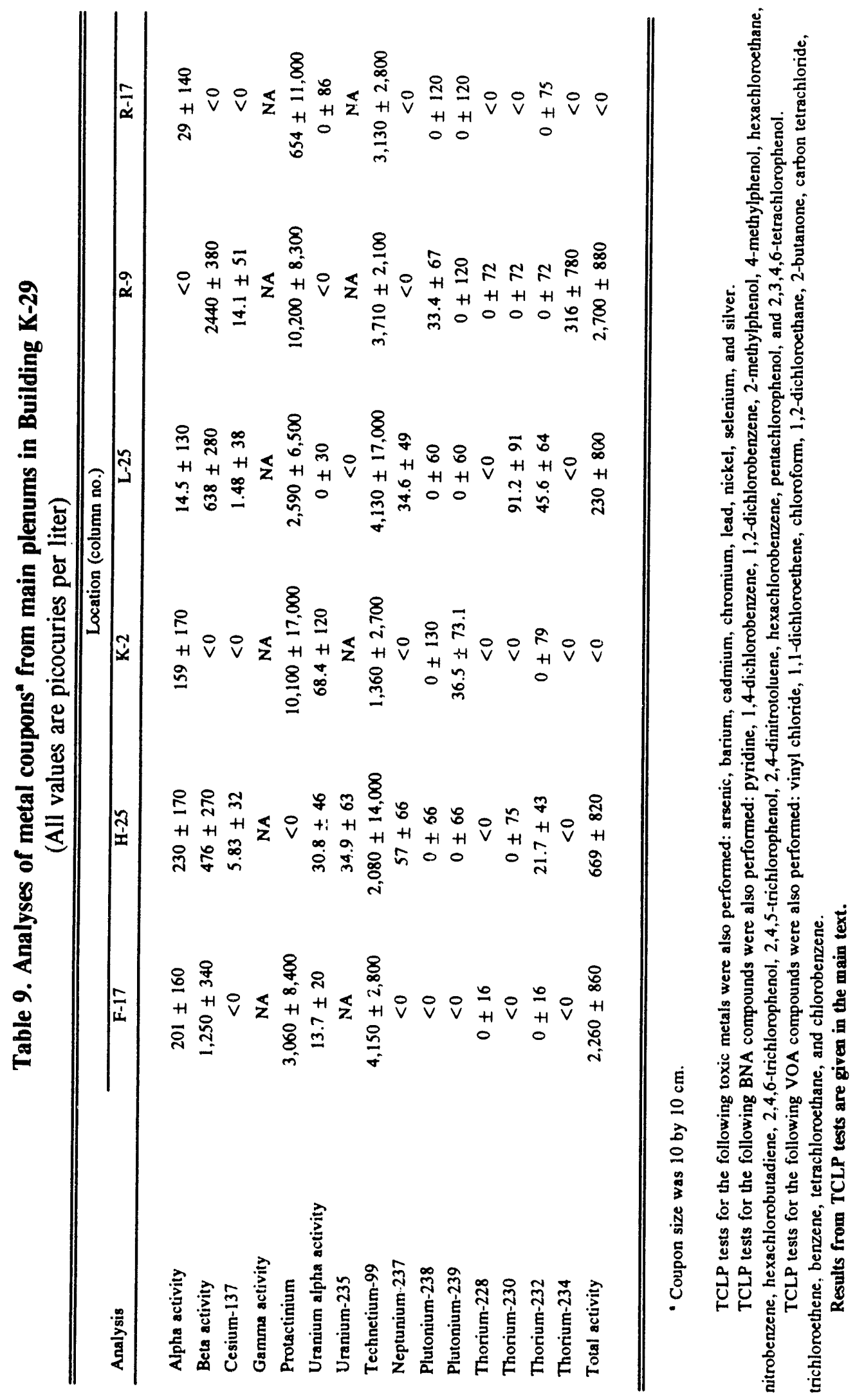




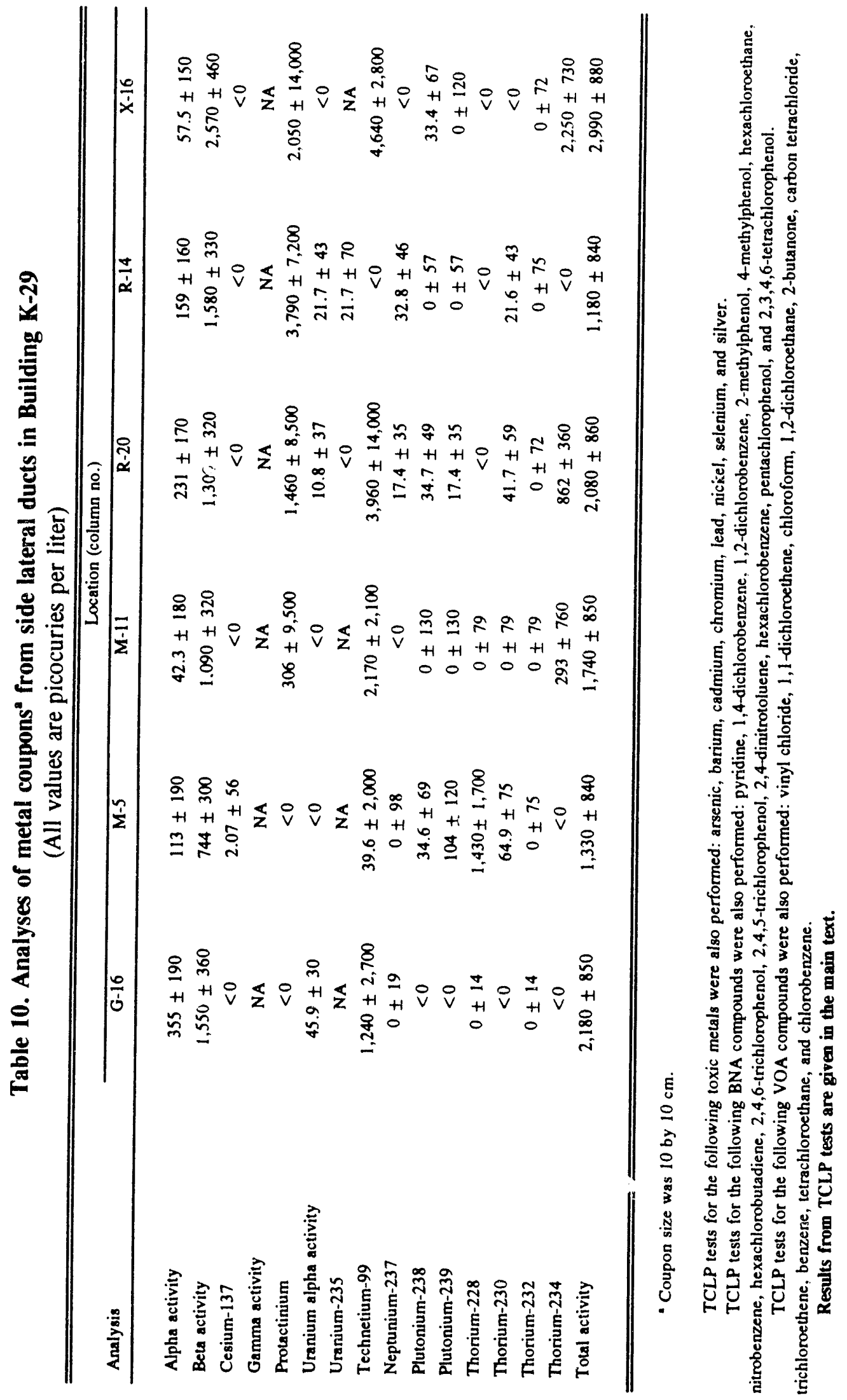


Table 11. Analyses of compesite bulk sample taken from side lateral duct at locations W-15, E-3, and B-5 in Building K-29

\begin{tabular}{l}
\hline Analysis \\
\hline \\
Alpha Activity \\
Beta Activity \\
Gamma Activity \\
Protactinium \\
Uranium Alpha Activity \\
Technetium-99 \\
Neptunium-237 \\
Plutonium-238 \\
Plutonium-239 \\
Thorium-228 \\
Thorium-230 \\
Thorium-232 \\
Total Activity
\end{tabular}

Detcrted Amount

Radionuclides ( $\mathrm{pCi} / \mathrm{s})$

Alpha Activity

$1170 \pm 22$

NA

$0.527 \pm 0.19$

$955 \pm 46$

$1410 \pm 210$

$<0 \pm 3.6$

$1.82 \pm 2.6$

$0 \pm 2.6$

$<0 \pm 3.9$

$36.3 \pm 14$

$6.8 \pm 6.4$

$2460 \pm 47$

$\underline{\text { TCLP/Metals }(m g / L)}$

Arsenic

$<0.50$

Barium

$<1.0$

Cadmium

1.1

Chromium

0.24

Lead

$<0.50$

Nickel

1.6

Selenium

$<0.50$

Silver

$<0.070$ 
Table 11 (continued)

\begin{tabular}{|c|c|}
\hline Analysis & Detected Amount \\
\hline \multicolumn{2}{|c|}{$\underline{T C L P / B N A s \quad(\mu g / L)}$} \\
\hline Pyridine & $\mathrm{U}^{*}$ \\
\hline 4-Dichlorobenzene & $\mathrm{U}$ \\
\hline 1,2-Dichlorobenzene & $\mathrm{U}$ \\
\hline 2-Methylphenol & $\mathrm{U}$ \\
\hline 4-Methylphenol & $\mathrm{U}$ \\
\hline Hexachloroethane & $\mathrm{U}$ \\
\hline Nitrobenzene & $\mathrm{U}$ \\
\hline Hexachlorobutadiene & $\mathrm{U}$ \\
\hline 2,4,6-Trichlorophenol & $\mathrm{U}$ \\
\hline 2,4,5-Trichlorophenol & $\mathrm{U}$ \\
\hline 2,4-Dinitrotoluene & $\mathrm{U}$ \\
\hline Hexachlorobenzene & $\mathrm{U}$ \\
\hline Pentachlorophenol & 13 \\
\hline 2,3,4,6-Tetrachlorophenol & $\mathrm{U}$ \\
\hline \multicolumn{2}{|c|}{ TCLP/VOAS $(\mu \mathrm{g} / L)$} \\
\hline Vinyl chloride & $U$ \\
\hline 1,1-Dichloroethene & $\mathrm{U}$ \\
\hline Chloroform & U \\
\hline 1,2-Dichloroethane & $\mathrm{U}$ \\
\hline 2-Butanone & 75 \\
\hline Carbon tetrachloride & $\mathrm{U}$ \\
\hline Trichloroethene & $\mathrm{U}$ \\
\hline Benzene & $\mathrm{U}$ \\
\hline Tetrachloroethane & $\mathrm{U}$ \\
\hline Chlorobenzene & $\mathrm{U}$ \\
\hline
\end{tabular}

$\cdot \mathrm{U}=$ undetected 


\section{DISCUSSION}

As noted in Table 5, the estimated range of PCB surface contamination exceeds 10 $\mu \mathrm{g} / 100 \mathrm{~cm}^{2}$, the Martin Marietta Energy Systems, Inc., mandated cleanliness standard for either high- or low-contact PCB-contaminated surfaces for all of the major plenums. The highest surface contamination was found in plenum number 2 (at location X-2), where the contamination was $51,000 \mu \mathrm{g} / 100 \mathrm{~cm}^{2}$. The sampling crew noticed a thin layer of oil inside the duct close to the gasket at this location.

Main plenum number 2 with the highest estimated range of PCB surface contamination also contained the highest estimated range of uranium. Plenum number 2 (at location X-2), which is located along the west side of the building, had a maximum surface contamination of $1200 \mu \mathrm{g}$ uranium $/ 100 \mathrm{~cm}^{2}$, and plenum number 25 (east side of $\mathrm{K}-29$ ) had a maximum surface contamination of $21,800 \mathrm{pCi}$ technetium $/ 100 \mathrm{~cm}^{2}$. Assuming that all contamination was removable and that the uranium was natural uranium, the highest detected levels of uranium (in plenum 2) and technetium (in plenum 25) are equivalent to $1800 \mathrm{dpm}$ (disintegrations/min) alpha and 48,400 dpm beta respectively. There was no obvious relationship between the uranium and technetium analyses. The levels of radiological contamination found would classify the main ducts (see Table 4) as contamination areas according to Energy Systems' standards for radiation protection and its interpretation of Attachment 2 of DOE Order 5480.11.

Mean levels of surface contamination for PCB in side laterals, shown in Table 7, were lower than the levels found in the main plenums. The overall mean for the analyses shown in Table 6 is $209 \mu \mathrm{g} \mathrm{PCB} / 100 \mathrm{~cm}^{2}(\mathrm{~s}=895)$ compared with $869 \mu \mathrm{g} \mathrm{PCB} / 100 \mathrm{~cm}^{2}$ (s = 6580) for the main plenums in Table 3. Generally, uranium contamination of the side laterals was higher than that found in the main plenums. The mean level (from Table 6) in the side laterals was $1030 \mu \mathrm{g} / 100 \mathrm{~cm}^{2}(\mathrm{~s}=2460)$ compared with $312 \mu \mathrm{g} / 100 \mathrm{~cm}^{2}(\mathrm{~s}=256)$ in the main plenums (based on data in Table 3). Technetium levels were also higher in the side laterals than in the main plenums. The mean level for technetium in Table 6 is $15,500 \mathrm{pCi} / 100 \mathrm{~cm}^{2}(\mathrm{~s}=21,200)$, while the mean for the main plenums in Table 3 is $5570 \mathrm{pCi} / 100 \mathrm{~cm}^{2}(\mathrm{~s}=4490)$.

The mean values in the side laterals (see Table 7) are above the Martin Marietta Energy Systems, Inc., PCB cleanliness standard, and the mean radiological levels in the side laterals would classify these as contamination areas based on alpha and beta activities according to the Energy Systems' listed levels. 
Based on the vipe analyses, the following overall tolerance limits for Building K-29 may be set so that one can say, with $95 \%$ confidence, that $95 \%$ of the contamination levels in the ductwork fall within these limits.

\section{Main plenums Side lateral ducts}

$\begin{array}{lcc}\text { PCB }\left(\mu \mathrm{g} / 100 \mathrm{~cm}^{2}\right) & 0-16,200 & 0-2,300 \\ \text { Uranium }\left(\mu \mathrm{g} / 100 \mathrm{~cm}^{2}\right)^{-\infty} & 0-910 & 0-6,770 \\ \text { Technetium }\left(\mathrm{pCi} / 100 \mathrm{~cm}^{2}\right)^{\cdots-} & 0-16,100 & 0-65,000\end{array}$

The above-listed ranges are based on the equation

$$
\overline{\mathrm{x}} \pm \mathrm{ks} \text {. }
$$

were $\bar{x}$ is the mean, $s$ is the sample standard deviation, and $k$ may be found in statistical tables.

The radiological analyses of the 12 coupon samples did not reveal surprising results. The highest activity detected was from the sample collected on a side lateral at location X-16, where the total activity was measured as $2990 \mathrm{pCi} / \mathrm{L}$ in the extract. In general, the side laterals appeared to be more contaminated, with all of the coupons samples having significant (aboveerror) total activity.

The TCLP tests indicated concentrations of mftals as follows: $0.032 \mathrm{mg} / \mathrm{L}$ cadmium and $0.38 \mathrm{mg} / \mathrm{L}$ nickel in the side lateral at $\mathrm{X}-16$, and $0.032 \mathrm{mg} / \mathrm{L}$ cadmium in the main plenum at R-17. The TCLP/BNA testing revealed no detectable BNA compounds in any of the coupon samples. Results from the TCLP/VOA assays indicated that an estimated $17 \mu \mathrm{g} / \mathrm{L}$ of 2 -hutanone was present in the sample from side lateral at G-16, and an estimated $19 \mu \mathrm{g} / \mathrm{L}$ of 2-butanone was present in the samples from the main plenum at K-2, R-9, and R-17. Samples from the side (1990).

•. K. Taylor, Statistical Techniques for Dara Analysis, Lewis Publishers, Inc., Chelsea, Mich., p. 70

-Assuming the uranium was present as natural uranium, the upper values listed compare with 1350 and $10,000 \mathrm{dpm} \alpha / 100 \mathrm{~cm}^{2}$ for the main and side lateral ducts respectively.

The upper values listed of technetium correspond to 35,700 and $144,000 \mathrm{dpm} \beta / 100 \mathrm{~cm}^{2}$ in the main and side lateral ducts respectively. 
lateral at M-11 and X-16 and a sample from the main plenum at location M-25 revealed $20 \mu \mathrm{g} / \mathrm{L}$ of 2-butanone. No other compounds were detected in the coupon samples.

Analyses of the composite bulk sample revealed a total activity of $2460 \mathrm{pCi} / \mathrm{g}$. Cadmium, chromium, and nickel were found in the bulk sample in concentrations of $1.2,0.24$, and 1.6 $\mathrm{mg} / \mathrm{L}$ respectively. Also found in the bulk sample were $13 \mu \mathrm{g} / \mathrm{L}$ pentachlorophenol and $75 \mu \mathrm{g} / \mathrm{L}$ 2-butanone.

NOTE: All negative values listed on analytical reports for technetium levels have been listed in this report as zero. This principle also applies to all statistical techniques performed. 
Appendix A- SAMPLE ID NUMBERS 
Table A.1. Sample ID numbers

\begin{tabular}{|c|c|c|c|c|c|}
\hline \multirow[b]{2}{*}{ Sample no. } & \multicolumn{2}{|c|}{$\begin{array}{l}\text { Sample ID as recorded by K-25's } \\
\text { Analytical Chemistry Department }\end{array}$} & \multirow[b]{2}{*}{ Sample no. } & \multicolumn{2}{|c|}{$\begin{array}{l}\text { Sample ID as recorded by K-25's } \\
\text { Analytical Chemistry Department }\end{array}$} \\
\hline & $\begin{array}{l}\text { Main plenum } \\
\text { sample }\end{array}$ & $\begin{array}{l}\text { Side lateral } \\
\text { duct sampie }\end{array}$ & & $\begin{array}{l}\text { Main plenum } \\
\text { sample }\end{array}$ & $\begin{array}{l}\text { Side lateral duct } \\
\text { sample }\end{array}$ \\
\hline 1 & K29-B1TW & K29S-B3W & 31 & K29M-N9W & K29S-L2W \\
\hline 2 & K29-B25W & K29S-B5W & 32 & K29M-N17W & K29S-L14W \\
\hline 3 & K29M-C2W & K29S-C2W & 33 & K29M-N25W & K29S-L19W \\
\hline 4 & K29M-C17W & K29S-C7W & 34 & K29M-O2W & K29S-M5W \\
\hline 5 & K29M-C25W & K29S-C15W & 35 & K29M-O9W & K29S-M11W \\
\hline 6 & K29M-D2W & K29S-D18W & 36 & K29M-O17W & K29S-N8W \\
\hline 7 & K29M-D17W & K29S-D23W & 37 & K29M-O25W & K29S-N16W \\
\hline 8 & K29M-D25W & K29S-E3W & 38 & K29M-P2W & K29S-N17W \\
\hline 9 & K29M-E17W & K29S-E13W & 39 & K29M-P9W & K29S-018W \\
\hline 10 & K29M-F2W & K29S-E15W & 40 & K29M-P25W & K29S-Q4W \\
\hline 11 & K29M-F17W & K29S-E23W & 41 & K29M-Q9W & K29S-Q9W \\
\hline 12 & K29M-G2W & K29S-G2W & 42 & K29M-Q17W & K29S-Q19W \\
\hline 13 & K29M-G1TW & K29S-G4W & 43 & K29M-Q25W & K29S-Q22W \\
\hline 14 & K29M-G25W & K29S-G16W & 44 & K29M-R2W & K29S-Q23W \\
\hline 15 & K29M-H2W & K29S-G18W & 45 & K29M-R9W & K29S-R6W \\
\hline 16 & K29M-H9W & K29S-H5W & 46 & K29M-R17W & K29S-S6W \\
\hline 17 & $\mathrm{~K} 29 \mathrm{M}-\mathrm{H} 17 \mathrm{~W}$ & K29S-H12W & 47 & K29M-R25W & K29S-S14W \\
\hline 18 & K29M-19W & K29S-H14W & 48 & K29M-S2W & K29S-S25W \\
\hline 19 & K29M-I17W & K29S-19W & 49 & K29M-S9W & K29S-T6W \\
\hline 20 & K29M-125W & K29S-I12W & 50 & K29M-T2W & K29S-T21W \\
\hline 21 & K29M-J2W & K29S-I13W & 51 & K29M-T9W & K29S-T24W \\
\hline 22 & K29M-J17W & K29S-J2W & 52 & K29M-T17W & K29S-U6W \\
\hline 23 & K29M-K2W & K29M-J10W & 53 & K29M-T25W & K29S-U14W \\
\hline 24 & K29M-K9W & K29S-J11W & 54 & K29M-U17W & K29S-U22W \\
\hline 25 & K29M-L.9W & K29S-J18W & 55 & K29M-U25W & K29S-V4W \\
\hline 26 & K29M-M2W & K29S-K4W & 56 & K29M-V2W & K29S-V10W \\
\hline 27 & K29M-M9W & K29S-K12W & 57 & K29M-V9W & K29S-V22W \\
\hline 28 & K29M-M17W & K29S-K15W & 58 & K29M-V17W & K29S-W15W \\
\hline 29 & K29M-M25W & K29S-K18W & 59 & K29M-X2W & K29S-W16W \\
\hline 30 & K29M-N2W & K29S-K22W & 60 & K29S-X4W" & K29S-X21W \\
\hline
\end{tabular}

-The listed ID does not exactly match the ID number listed in the field logbook. 
Appendix B- RESULTS OF DUPLICATE WIPE ANALYSES IN BUILDING K-29 
Table B.1. Results of duplicate wipe analyses in Building K-29

\begin{tabular}{|c|c|c|c|c|c|c|}
\hline \multirow[b]{3}{*}{$\begin{array}{c}\text { Column } \\
\text { no. }\end{array}$} & \multicolumn{6}{|c|}{ Analysis } \\
\hline & \multicolumn{2}{|c|}{$\begin{array}{c}\text { PCB } \\
\left(\mu \mathrm{g} / 100 \mathrm{~cm}^{2}\right)\end{array}$} & \multicolumn{2}{|c|}{$\begin{array}{c}\text { Uranium } \\
\left(\mu \mathrm{g} / 100 \mathrm{~cm}^{2}\right)\end{array}$} & \multicolumn{2}{|c|}{$\begin{array}{l}\text { Technetium } \\
\left(\mathrm{pCi} / 100 \mathrm{~cm}^{2}\right)\end{array}$} \\
\hline & Original & Duplicate & Original & Duplicate & Original & Duplicate \\
\hline \multicolumn{7}{|c|}{ Main plenums } \\
\hline H-25 & 2.1 & 1.6 & 91 & 100 & 240 & 2670 \\
\hline F-17 & 77 & 170 & 120 & 140 & 3,150 & 2710 \\
\hline $\mathrm{K}-2$ & 23 & 8.1 & 740 & 1,100 & 3,450 & 3770 \\
\hline M-25 & 91 & 51 & 140 & 200 & 5,550 & 5020 \\
\hline R-9 & 17 & 17 & 170 & 160 & 5,430 & 6930 \\
\hline $\mathrm{R}-17$ & 5 & 5.5 & 99 & 70 & 8,690 & 5590 \\
\hline \multicolumn{7}{|c|}{ Side lateral ducts } \\
\hline G-16 & 50 & 30 & 2,100 & 660 & 14,600 & 11,400 \\
\hline M-5 & 31 & 14 & 360 & 350 & 15,300 & 35,300 \\
\hline M-11 & 92 & 73 & 230 & 270 & 908 & 264 \\
\hline$R-20$ & 14 & 15 & 980 & 830 & 16,300 & 8,960 \\
\hline \multirow[t]{2}{*}{$R-14$} & 8.3 & 16 & 140 & 300 & 19,000 & 12,100 \\
\hline & \multicolumn{2}{|c|}{$\mathrm{sp}^{\mathrm{n}}=33.9$} & \multicolumn{2}{|c|}{$s p=472$} & \multicolumn{2}{|c|}{$\mathrm{sp}=6,949$} \\
\hline
\end{tabular}

"The standard deviation listed is the pooled standard deviation [J. K. Taylor, Statistical Techniques for Data Analysis, Lewis Publishers, Inc., Chelsea, Mich., p. 46 (1990)]. 


\section{Distribution List}

\section{INTERNAL DISTRIBUTION}

1. C. H. Brown, Jr.

2-6. S. L. Corder

7. A. G. Croff

8. T. L. Donaldson

9. F. M. Faulcon

10. R. K. Genung

11. R. A. Joseph, Jr.

12. D. R. Kelsheimer

13-17. K. T. Klasson

18. S. M. Robinson

19. E. J. Roy

20. M. K. Savage

21. C. W. Snodgrass

22-31. V. L. Turner

32. Central Research Library

33. Y-12 Technical Library, Document Reference Section

34-35. Laboratory Records

36. Laboratory Records, RC

37. ORNL Patent Section

\section{EXTERNAL DISTRIBUTION}

38. Office of Assistant Manager, Energy Research and Development, DOE-ORO, P.O. Box 2001, Oak Ridge, TN 37831

39-40. Office of Scientific and Technical Information, P.O. Box 62, Oak Ridge, TN 37831 

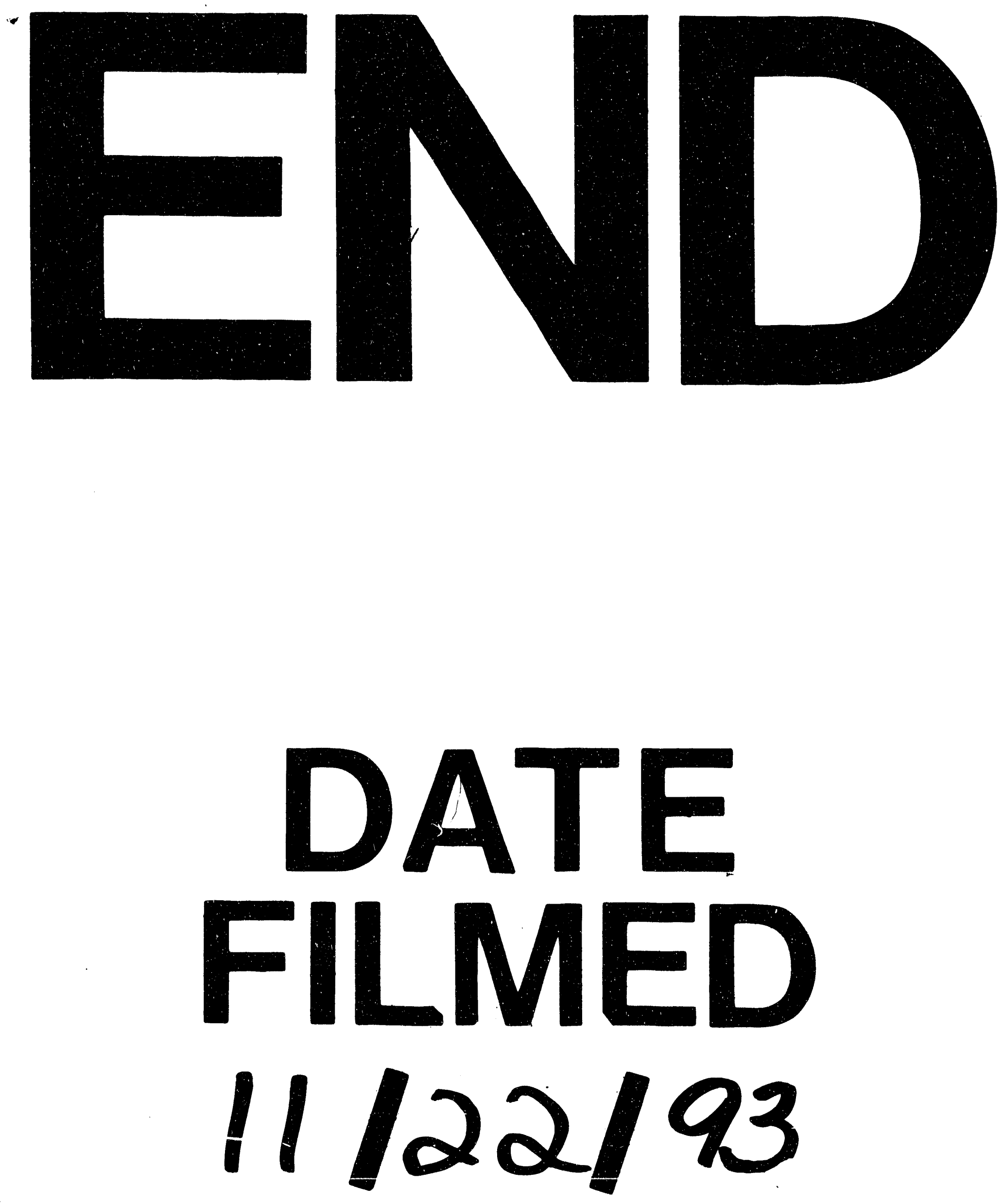
